\title{
Electroless Ni-B plating for electrical contact applications
}

\author{
C.T. Dervos*, P. Vassiliou** and J. Novakovic*
}

\begin{abstract}
Electroless $\mathrm{Ni}$-B plating has been tried on steel substrate in an effort to employ low-cost starting materials for electrical contacts or connectors. By selected conditions of heat treatment in a high vacuum environment the plating can acquire $\mathrm{Cr}$-equivalent hardness without the effluents of the hard chromium plating process. The surfaces were characterized under scanning electron microscope and by XRD. The fabricated materials were tested under corrosion conditions by polarization measurements. Semispherical nickel plated steel joints were tested in a computer controlled contact make-break apparatus, under simultaneous application of a mechanical and a low-voltage electrical load for 20,000 cycles. After heat treatment the plating acquires a crystalline structure with very good adhesion to the substrate material. Corrosion decreases and increased hardness is obtained. The surface is also characterized by good electrical properties during aging accelerated tests.
\end{abstract}

Keywords Ni-B electroless plating. Heat treatment. Electrical contacts.

\section{Deposición de Ni-B por vía química para aplicaciones de contacto eléctrico}

\begin{abstract}
Resumen Se ha investigado la deposición de Ni-B por vía química sobre un substrato de acero, con el fin de poder emplear materiales de bajo coste para los contactos o conectores eléctricos. Mediante condiciones específicas de tratamiento térmico en un ambiente de alto vacío, la deposición puede alcanzar durezas equivalentes al cromo $(\mathrm{Cr})$ sin los efluentes del proceso de cromado duro. Las superficies se caracterizaron en el microscopio electrónico de barrido y mediante DRX. Los materiales fabricados se ensayaron bajo condiciones de corrosión utilizando mediciones de polarización. Se ensayaron las juntas semiesféricas de acero niquelado en un equipo de contactos controlado por ordenador bajo la aplicación simultánea de una carga mecánica y de una carga eléctrica de bajo voltaje durante 20.000 ciclos. Después del tratamiento térmico, el recubrimiento adquiere una estructura cristalina con muy buena adherencia al material del substrato. Se consigue una menor corrosión y mayor dureza. La superficie también se caracteriza por sus buenas propiedades eléctricas durante los ensayos de envejecimiento acelerado.
\end{abstract}

Palabras clave Deposición de Ni-B por vía química. Tratamiento térmico. Contactos eléctricos.

\section{INTRODUCTION}

Several case studies of electrical failures have shown that environmental contamination slips in between stationary contact joints and settles on or corrodes the electrical contacts ${ }^{[1]}$. All stationary electrical contact types are required to have low (of the order of milliohm or less) stable contact resistance during servicing periods, which may exceed up to 40 years. Bare metal stationary contacts often develop a high contact resistance while in operation. Recent theoretical and experimental studies have established that the interfacial resistance growth in the field can be mainly attributed to mechanical degradation (tracks of fretting) ${ }^{[2-5]}$, electrical degradation (erosion) $)^{[6]}$, and environmental contamination ${ }^{[7]}$.

Contact material fabrication techniques may substantially improve the overall component performance. The work presented in this paper exploits the possibility of using electroless $\mathrm{Ni}-\mathrm{B}$ coatings as external protective layer of electrical

$\left(^{*}\right)$ School of Electrical and Computer Engineering, National Technical University of Athens 9, Iroon Polytechniou Str, Zografou 15773, Athens, Greece. Email: cdervos@central.ntua.gr

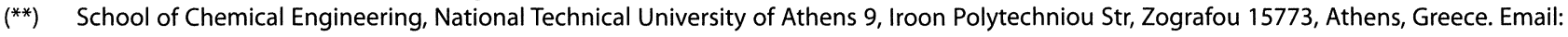
pvas@chemeng.ntua.gr 
connectors. It aims to the provision of a corrosion resistant layer with chromium equivalent hardness and stable electrical characteristics in order to be used as stationary, (or sliding) electrical contacts operating in adverse environments (i.e. synergy effect of fretting and pollution). Potent applications might be found within the areas of naval, aircraft and vehicular technologies.

Electroless nickel is an engineering coating, normally employed because of its excellent corrosion and wear resistance. Due to these properties, electroless nickel coatings have found many applications, including those in petroleum, chemicals, plastics, optics, printing, aerospace, nuclear, automotive electronics, computers textiles, paper and food machinery ${ }^{[8]}$.

The properties of deposits from borohydride or aminoborane reduced baths are similar to those of electroless Ni-P alloys with few exceptions. The hardness of Ni-B alloys is very high, and these alloys can be heat treated to levels greater than that of hard chromium. Similarly to Ni-P, $\mathrm{Ni}-\mathrm{B}$ deposit characteristics change with boron content ${ }^{[9]}$. The amount of boron contained in borohydride electroless nickel coatings ranges between 1 and $10 \%$ weight $^{[10]}$. The structure of the deposits is a mixture of microcrystalline nickel and amorphous $\mathrm{Ni}-\mathrm{B}$ phases in the as deposited condition. The quantity of amorphous phase increases with boron content ${ }^{[11-14]}$. The melting point of a $5 \% \mathrm{~B}$ coating is relatively high $\left(1080^{\circ} \mathrm{C}\right.$ for $\mathrm{Ni}-\mathrm{B}$ in comparison to $890^{\circ} \mathrm{C}$ for $\mathrm{Ni}-\mathrm{P})$. The electrical resistivity of these coatings is similar to that of nickel-phosphorus alloys, ranging from $89 \mu \Omega \cdot \mathrm{cm}$ in the as deposited condition to $43 \mu \Omega \cdot \mathrm{cm}$ after heat treatment at $1,100{ }^{\circ} \mathrm{C}^{[15]}$

The principal advantage of electroless nickelboron is its high hardness and superior wear and mechanical resistance. In the as deposited condition, microhardness values of 650 to 750 $\mathrm{HV}_{100}$ are typical for borohydride reduced coatings. After 1-h heat treatments in inert gas atmosphere at 350 to $400{ }^{\circ} \mathrm{C}$, hardness values of $1,200 \mathrm{HV}_{100}$ can be produced ${ }^{[15]}$. Long-term treatments (30 to 40 weeks) at temperatures between 200 and $300{ }^{\circ} \mathrm{C}$ can produce hardness values of 1,700 to 2,000 $\mathrm{HV}_{100}{ }^{[14-16]}$. These low temperature treatments result in a finer dispersion of nickel boride and in the formation of iron borides within the coating. After heat treatment the wear resistance of electroless nickel-boron is equal or exceeds that of hard chromium coatings.

\section{EXPERIMENTAL}

\subsection{Sample fabrication process}

The substrates used were either planar carbon steel coupons $2 \times 1 \times 0.1 \mathrm{~cm}$ or semispherical with the geometry shown in figure 1 . The semispherical sample geometry was preferred for the electrical characterization and fretting response of the examined materials. Before coating the samples were mechanically cleaned from corrosion products. Subsequently, they were degreased with acetone, detergent solution and rinsed in distilled water. The sample surfaces were finally activated with a $15 \%$ solution of $\mathrm{HCl}$ for 1 min, rinsed in distilled water and submerged in the deposition bath. The chemical composition of the electroless $\mathrm{Ni}-\mathrm{B}$ bath is given in table I.

The deposition was conducted at $95{ }^{\circ} \mathrm{C}$, maintaining a ratio of solution volume to deposition area of approximately $25 \mathrm{ml} / \mathrm{cm}^{2}$. The deposition time was $3 \mathrm{~h}$, during which, the bath was kept slightly agitated by rotation of the specimen to be coated with a mechanical stirring rod at a speed of 50 revs/min. Bath replenishment was achieved by regular additions of replenishment solution, which is made by dissolving sodium borohydride in the $1 \mathrm{M}$ solution of sodium hydroxide.

To augment the surface hardness of the produced layers, the fabricated samples were thermally treated in a high vacuum environment pumped by a $300 \mathrm{l} / \mathrm{s}$

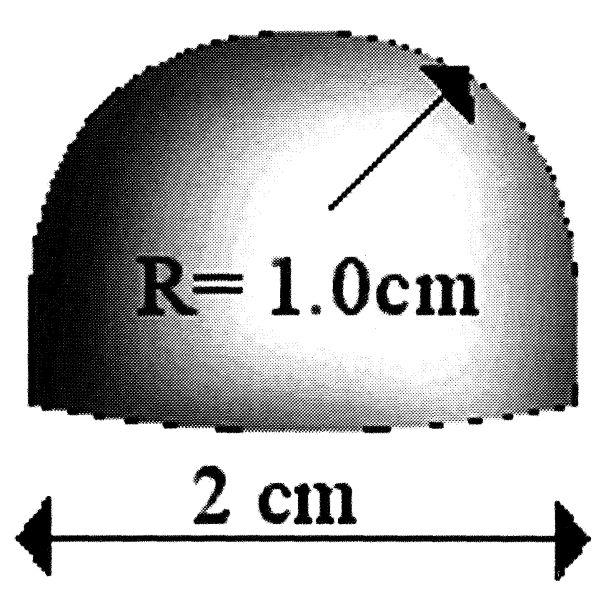

Figure 1. The geometry and the dimensions of the examined semispherical contact materials. Selected materials: Electroless $\mathrm{Ni}$ - $\mathrm{B}$ deposit of approximate thickness of 30 microns on a steel substrate.

Figura 1. Geometría y dimensiones de los materiales con forma semi esférica estudiados. Sobre un substrato de acero se aplicó un depósito químico de Ni-B de 30 micrometros de espesor. 
Table I. Chemical composition of employed Ni-B bath

Tabla I. Composición química del baño de Ni-B empleado

\begin{tabular}{lcl}
\hline Bath composition & & g /I \\
\hline Metallic ions & $\mathrm{NiCl}_{2} \times 6 \mathrm{H}_{2} \mathrm{O}$ & 20 \\
Alkalinity reserve & $\mathrm{NaOH}$ & 39 \\
Complexing agent & $\mathrm{NH}_{2}-\mathrm{CH}_{2}-\mathrm{CH}_{2}-\mathrm{NH}_{2}$ & 59 \\
Stabilizer & ${\mathrm{Pb}\left(\mathrm{NO}_{3}\right)_{2}}^{2}$ & 0.0145 \\
Reducing agent & $\mathrm{NaBH}_{4}$ & 0.48 \\
\hline
\end{tabular}

diffusion pump. The samples were heated at temperatures of the order of $850^{\circ} \mathrm{C}$, using a Mo foil resistor (purity $99.9 \%$, thickness $0.15 \mathrm{~mm}$ ) and controlling the a.c. current flow for a period of 5 min. During the heating process the total pressure in the chamber was maintained below $4 \times 10^{-5} \mathrm{mbar}$. Then, the samples were allowed to cool down, for $30 \mathrm{~min}$, in a high vacuum environment prior to their exposure to the atmosphere.

\subsection{Sample characterization}

The following characterization methods were employed in order to determine the quality and physical properties of the produced coatings:

- Profilometry.

- Vickers microhardness measurements were carried out on the deposit by employing a load of $100 \mathrm{~g}$ for a period of $10 \mathrm{~s}$. The specimen microhardness was evaluated by averaging five experimental runs.

- Optical observations of the produced layers were based on Scanning Electron Microscopy SEM, and the chemical analysis of the deposits was determined by means of microanalysis EDS, (JEOL JSM 6100).

- The different precipitated phases of the deposits were analyzed by X-ray diffraction (SIEMENS $\mathrm{X}$-ray Diffractometer 5000) using $\mathrm{Cu} \mathrm{K \alpha} \mathrm{X}$-ray source.

- Corrosion resistance characterization of the deposits, by means of Tafel electrochemical measurements. Potentiodynamic polarization curves were taken on the specimens during their exposure to the electrolyte, which was an aqueous solution of $3.5 \% \mathrm{NaCl}$ at room temperature. A three-electrode electrochemical cell configuration was employed having a Saturated Calomel Electrode as a reference, and a platinum foil as a counter electrode, the third electrode being the tested specimen. The instrumentation was a CMS100 Gamry potentiostat, computer controlled, with commercial software for the data treatment.

- The electrical characterization of the deposits was based upon contact resistance monitoring during mechanical applied duty cycles. The apparatus used for the simultaneous application of electrical and mechanical load is presented in figure 2 . When the contacts were closed, the applied axial contact force could be varied between 0 and $5 \mathrm{~N}$. A computer-controlled apparatus was employed to operate fretting-action duty cycles, i.e. perform low amplitude contact displacements. Each duty cycle lasted for $6 \mathrm{~s}$, among which, 20 discrete contact displacements were performed. To superimpose electrical fatigue, the contact was opened and closed after each duty cycle and the contact resistance was monitored and plotted as a function of the duty cycles. A dc current flow of $20 \mathrm{~mA}$ was applied across the joints during these tests.

\section{RESULTS AND DISCUSSION}

\subsection{Characteristics of the deposit}

The typical microstructure of the electroless $\mathrm{Ni}-\mathrm{B}$ produced coating is illustrated in figure 3 . The

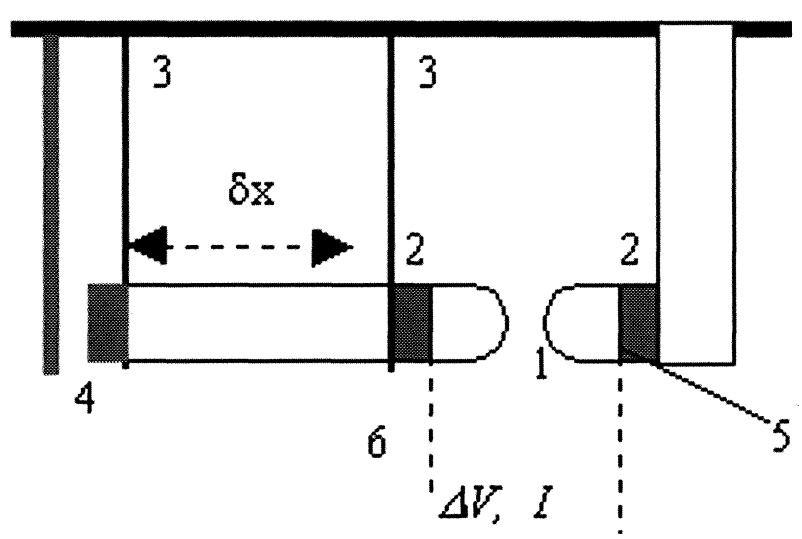

Figure 2. Layout of the mechanical apparatus: 1) Electrical contact joints. 2) Electrical insulators. 3) Phosphor-bronze spring allowing linear motion by $\mathrm{dx}$ to allow for contact opening. 4) Computer controlled magnetic circuit stimulating the low amplitude transverse displacement. 5) Transducer for axial contact force measurement. 6) Flexible current leads. Interfacial voltage, DV, and current, I, profiles could be digitally recorded.

Figura 2. Descripción del equipo utilizado: 1) contacto eléctrico, 2) aislante eléctrico, 3) mecanismo de contacto de fosforo-bronce, 4) equipo de control mediante ordenador, 5) medidores de fuerza de contacto, 6) cables. 

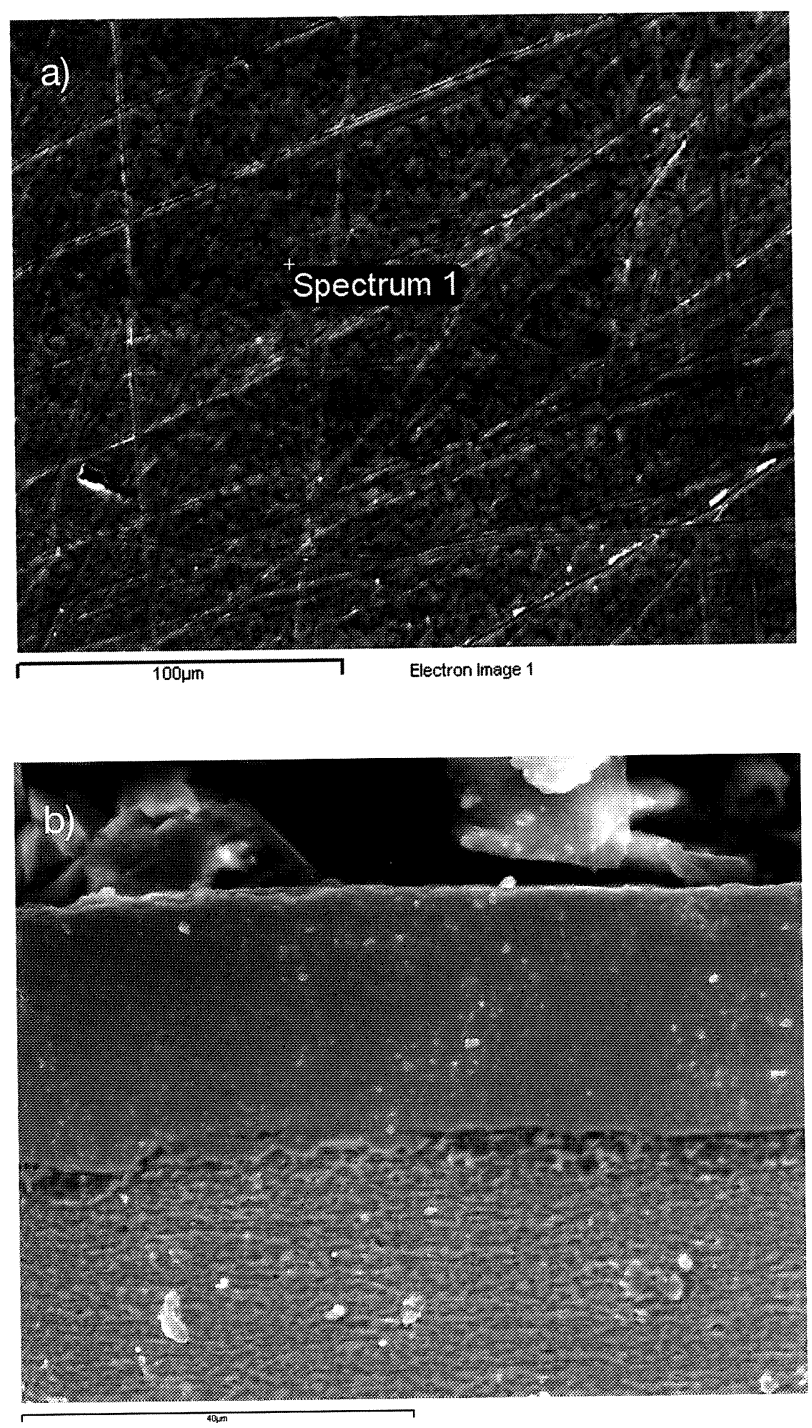

Figure 3. (a) SEM photo of the as-plated Ni-B deposit on steel substrate, (b) cross-section.

Figura 3. (a) Micrografía SEM de un depósito químico de Ni-B sobre substrato de acero, (b) corte transversal.

$\mathrm{Ni}-\mathrm{B}$ deposit present is uniform and adherent on the steel substrate.

The evaluation of the coating thickness by SEM microscopy and by gravimetric measurements before and after plating allowed the determination of a mean thickness value at about $25 \mu \mathrm{m}$. The conducted EDS analysis on the deposit revealed the boron content of approximately $5 \%$. Vickers microhardness measurements, determined with a load of $100 \mathrm{~g}$, were of the order of 1,000 $\pm 30 \mathrm{HV}$ for all the as-deposited samples - that is an exceptional high value for microhardness after the bath preparation. Typical microhardness values for borohydride reduced coatings are 650-750 HV ${ }^{[15]}$. The substrate material had a corresponding microhardness of the order of $270 \pm 5 \mathrm{HV}$. Roughness measurements for the substrate and the as-plated coatings showed that the $\mathrm{Ni}$ - $\mathrm{B}$ plating tends to make surface morphology smoother (Table II).

Figure 4 shows the diffraction pattern of $\mathrm{Ni}-\mathrm{B}$ deposit in as deposited condition. The presence of a mixture of one diffuse amorphous peak and sharp crystalline/microcrystalline nickel peaks can be noticed. The total XRD profile can be separated in the crystalline and amorphous one to take into account both structures ${ }^{[11-17]}$. The $\mathrm{Ni}-\mathrm{B}$ deposit is almost amorphous with an extremely fine $\mathrm{Ni}$ crystallized structure near the nanometer.

Typical corrosion rate for the fabricated $\mathrm{Ni}-\mathrm{B}$ layers was found to be $0.058 \mathrm{~mm} / \mathrm{yr}$ (Table III). Such corrosion rate of $\mathrm{Ni}-\mathrm{B}$ deposits is satisfactory ${ }^{[18]}$ but still greater than the corrosion rate obtained for the $\mathrm{Ni}$-P deposits $(0.019 \mathrm{~mm} / \mathrm{yr})$ fabricated in a similar way ${ }^{[19]}$. The above results are summarized in Table III.

Table II. Typical roughness measurements $(\mathrm{mm})$, and microhardness test results (HV) for the substrate material, the asplated layer and the vacuum heat treated sample

Tabla II. Rugosidad típica (mm) y microdureza (HV) del sustrato metálico, de la capa depositada y de la muestra tratada térmicamente al vacio

\begin{tabular}{lcccc}
\hline Sample & $\mathbf{R}_{\mathbf{a}}, \mu \mathrm{m}$ & $\mathbf{R}_{\mathrm{t}}, \mu \mathrm{m}$ & $\mathbf{R}_{\mathbf{z}} \mu \mathrm{m}$ & $\mathbf{M H T}, \mathbf{H V}$ \\
\hline Substrate & 0.58 & 4.7 & 3.4 & $270 \pm 5$ \\
Ni-B plated & 0.21 & 1.9 & 1.2 & $1,000 \pm 30$ \\
$\begin{array}{l}\text { Vacuum Heated } 850^{\circ} \mathrm{C}, \\
\quad 0.20\end{array}$ & 1.70 & 1.10 & $1,670 \pm 20$ \\
$\quad$ mmin & & & & \\
\hline
\end{tabular}

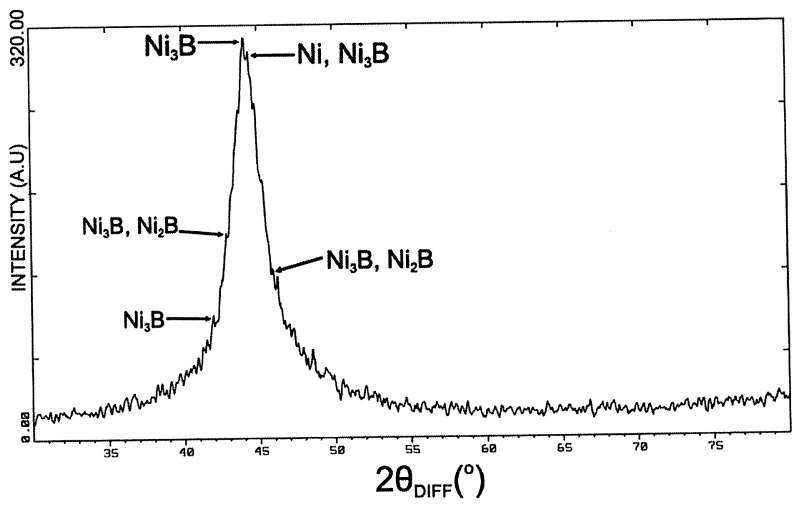

Figure 4. XRD pattern of the as-plated electroless Ni-B deposit.

Figura 4. Espectro DRX de un depósito químico de Ni-B. 
Table III. Tafel corrosion resistance results

Tabla III. Comportamiento frente a la corrosión, rectas de Tafel

\begin{tabular}{lcccc}
\hline & \multicolumn{5}{c}{ TAFEL RESULTS } \\
\cline { 2 - 6 } Ni-B deposit & $\mathbf{E}_{\text {corr }}$ & $\mathrm{I}_{\text {corr }}$ & $\mathbf{R}_{\mathrm{p}}$ & Corr. Rate \\
& $\mathrm{mV}$ & $\mu \mathrm{A} / \mathrm{cm}^{2}$ & $\mathrm{~m} \Omega / \mathrm{cm}^{2}$ & $\mathrm{~mm} / \mathrm{yr}$ \\
\hline As-plated & -536 & 4.858 & 10.69 & 0.058 \\
Vacuum heated 5 min. & -483 & 11.27 & 3.586 & 0.135 \\
\hline
\end{tabular}

\subsection{Effects of the heat treatment in a high vacuum}

After the heat treatment the deposits exhibit a bright sharp color and acquire an excessive surface microhardness, which is of the order of $1670 \mathrm{HV}$ following the $5 \mathrm{~min}$ thermal exposure at $850^{\circ} \mathrm{C}$ in a high vacuum. As stated previously, such high value of microhardness can be accomplished only after a prolonged heat treatment ( $30-40$ weeks) at a temperature range of $200-300{ }^{\circ} \mathrm{C}{ }^{[14]}$. Applied rapid vacuum heat treatment probably causes a fine dispersion of nickel boride and results in very high microhardness, which in some cases reaches 2,000 HV locally. All microhardness measurements were performed with a load of $100 \mathrm{~g}$ and without any deposit failures as has been reported ${ }^{[20]}$.

The corrosion rate of the vacuum heated samples was $0.135 \mathrm{~mm} /$ year and is greater than the corrosion rate of as-plated samples (Table III),

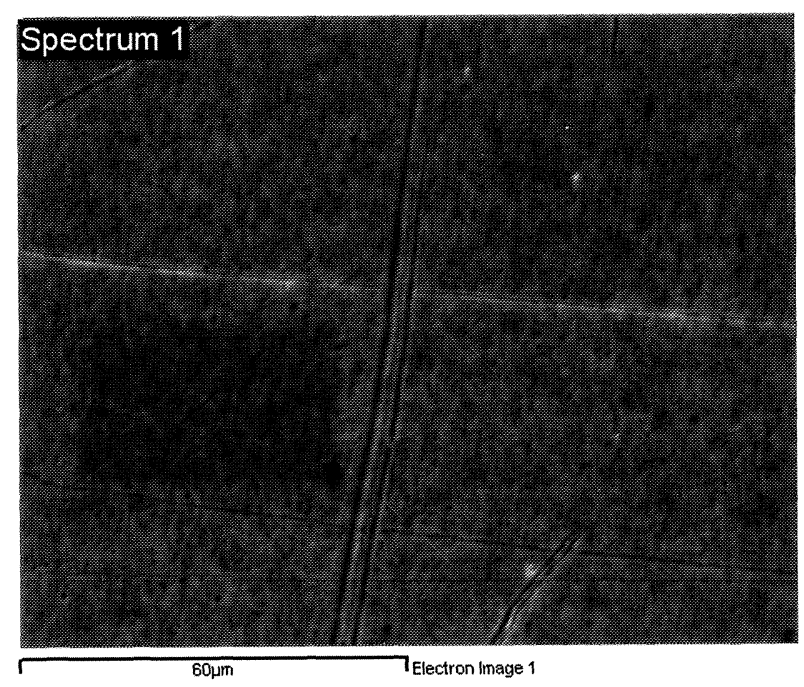

Figure 5. SEM photo of the thermally heated Ni-B deposit in a high vacuum environment.

Figura 5. Micrografía SEM de un depósito químico de Ni-B tratado térmicamente en un ambiente de alto vacio. although remains at satisfactory levels ${ }^{[18]}$. The crystallization process of $\mathrm{Ni}-\mathrm{B}$ deposits in a vacuum-heating environment may result in minute crack formations, consequently decreasing the corrosion resistance in the heated $\mathrm{Ni}$ - $\mathrm{B}$ deposits. This minute cracking could be also attributed to the different thermal expansion of the coating in relation to the steel substrate.

The XRD analysis shows that when Ni-B samples were heated under vacuum a number of sharp peaks corresponding to both the metal $\mathrm{Ni}$, $\mathrm{Ni}_{3} \mathrm{~B}$ and of the $\mathrm{Ni}_{2} \mathrm{~B}$ alloy phases appeared (Fig. 6). The structural change of the Ni-B coating during thermal treatment is primarily attributed to its crystallization onset at high temperatures.

XRD pattern of the as plated Ni-B deposit shows one peak around $2 \theta=45^{\circ}$ indicating that the structure of this deposit is extremely finely crystallized with a $\mathrm{Ni}$ crystal structure near the nanometer, which is almost amorphous. The total XRD profile can also be separated in the crystalline and amorphous ${ }^{[20]}$.

After the rapid thermal treatment in a high vacuum at elevated temperatures, the appearance of various sharp peaks in the XRD spectra indicated a rapid crystallization of the $\mathrm{Ni}-\mathrm{B}$ alloy. The crystallization degree was mainly accomplished beyond a temperature threshold of approx. $800{ }^{\circ} \mathrm{C}$ and beyond that, it was not very sensitive on temperature value and heating duration. It appeared that heating for up to $5 \mathrm{~min}$ results to complete crystallization of the $\mathrm{Ni}-\mathrm{B}$ layers. Therefore, one could conclude that the rearrangement of the alloy components and the decomposition of the Ni-B alloy occurred during the crystallization. The amorphous structure

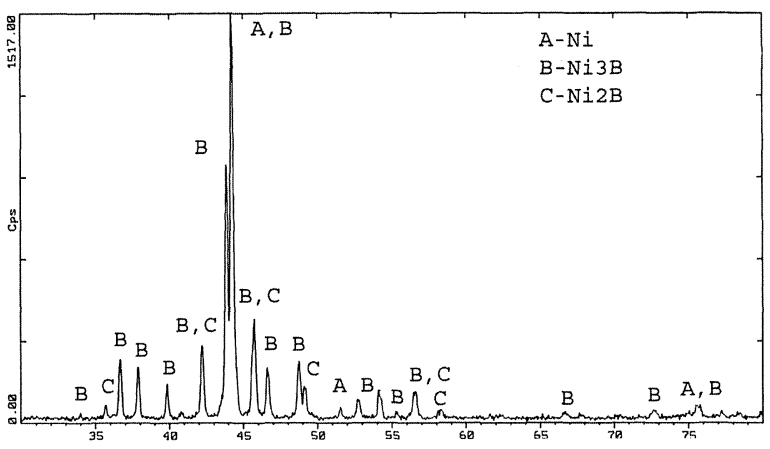

Figure 6. XRD pattern of the heat-treated Ni-B deposit at $850^{\circ} \mathrm{C}$ in a high vacuum environment.

Figura 6. Espectro $D R X$ de un depósito químico de Ni-B tratado térmicamente a $850{ }^{\circ} \mathrm{C}$ en un ambiente de alto vacio.

Rev. Metal. Madrid Vol. Extr. (2005) 232-238 
changes into a phase mixture of crystalline $\mathrm{Ni}$ and nickel boride, which leads to the occurrence of precipitation hardening. Particles of precipitate form when sufficient atoms diffuse to a particular location to form a volume of material that has stoichiometric composition and that is large enough so that a boundary can be formed around it. One should also mention, the all trapped by the reduction process gases (mainly $\mathrm{H}_{2}$ ) is removed by the pressure difference.

\subsection{The utilization of heat treated EN coatings as electrical contact materials}

Electroless nickel coatings on steel substrates, having the geometry shown in figure 1, were examined as potent stationary contact or connector materials. The electrical performance of the substrate material, during the combined mechanical and electrical accelerated aging showed relatively high contact resistance values, with great variations. This response is clearly demonstrated in figure $7 \mathrm{a}$. When the material was covered by an electroless nickel-boron coating ( 25 $\mu \mathrm{m}$ thick) the contact resistance dropped by at least a factor of ten, and also remained stable over many duty cycles (Fig. 7b). The improvement of contact resistance can be attributed to the lower resistivity of the coating and/or more effective heat dissipation properties.

During the contact make-break operations arcing may occur between the surface asperities of the moving electrode, depending on the applied test parameters. Though undesirable, the high temperature arcs are always present in electrical contacts and they may have the required energy to melt surface spots and to remove molten matter from the one pole to the other. This melting phenomenon evolves as a result of interfacial thermal dissipation and the immediate recrystallization was observed for the as-plated $\mathrm{Ni}$ B deposit (Fig. 8.). Vacuum heat treated Ni-B deposits do not show any melting after electrical testing (Fig. 9.), because the crystals formed have higher melting point than the microcrystalline material.

The electrical performance (Fig. 7b) shows that the as-plated $\mathrm{Ni}$-B coating has slightly lower contact resistance than the heat-treated coating. This can be attributed to an enlarged contact surface area created by the melting phenomenon observed on the as plated $\mathrm{Ni}-\mathrm{B}$ coatings. Also, when the surface material is displaced, by
Voltage drop, $V$

a)

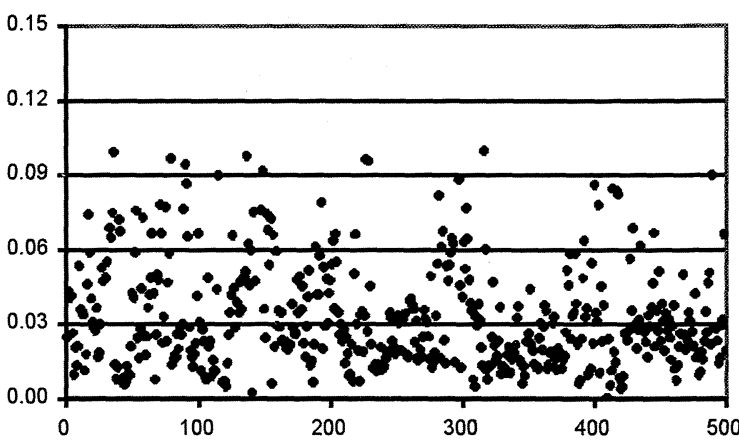

Duty Cycles

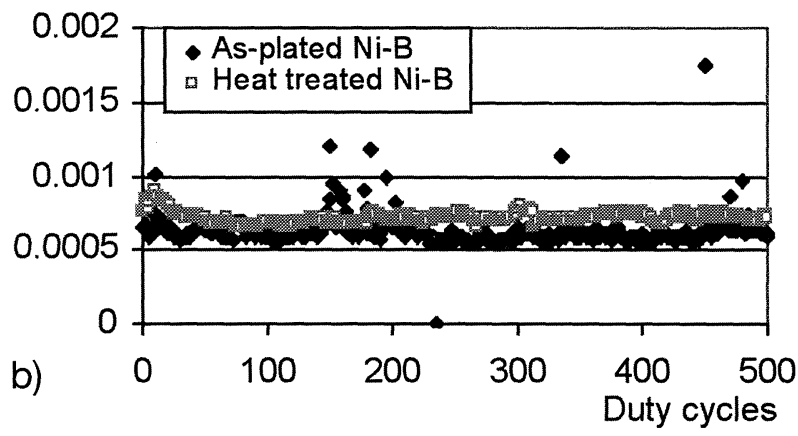

Figure 7. Contact potential drop as a function of mechanical duty cycles each one consisting of 20 discrete low amplitude linear displacements, with clamping force of $1 \mathrm{~N}$. The current flow during these measurements was $20 \mathrm{~mA} \mathrm{dc}$; hence the voltage drop values can be directly converted to contact resistance values. (a) Characteristics of the steel substrate material. (b) Comparison between as-plated Ni-B coating and the same coating after heat treatment in a high vacuum.

Figura 7. Caida de potencial en función de los ciclos mecánicos en servicio, (a) substrato de acero, (b) comparación del depósito químico sin tratar y tratado térmicamente.

electromigration, the substrate contributes to the charge transfer process across the contacts. Thus, it is observed a less regular behavior of contact resistance in this case than in the case of heattreated $\mathrm{Ni}-\mathrm{B}$ deposit. The employed vacuum heat treatment leads to crystalline nickel-nickel boride layers with significantly enhanced increased microhardness and good adhesion and wear properties which can be verified by very slightly variations of the contact resistance.

The provided results demonstrate clearly the advantages offered by the heat treatment in a vacuum of $\mathrm{Ni}-\mathrm{B}$ coatings. They also imply that this fabrication technique could be utilized for stationary contacts-connectors in specific applications, where stable low resistance values have to be maintained in adverse working 


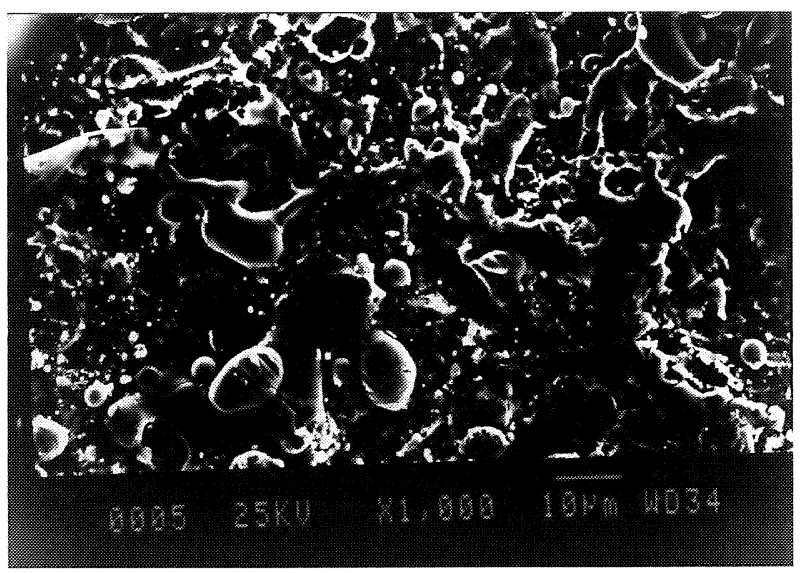

Figure 8. SEM photo of the surface of the as-plated $\mathrm{Ni}-\mathrm{B}$ coating after electrical testing. The melting and the recrystallization are seen on the contact surface.

Figura 8. Micrografía SEM de un depósito químico de Ni-B despues del ensayo eléctrico.

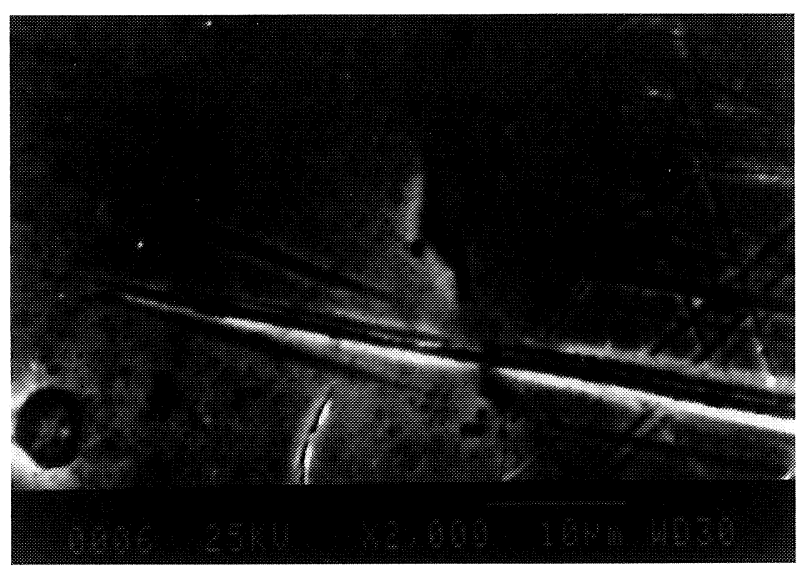

Figure 9. SEM photo of the surface of the heat-treated Ni-B coating after electrical testing.

Figura 9. Micrografía SEM de undepósito químico de Ni-B tratado térmicamente después del ensayo eléctrico.

conditions i.e. corrosive environment and/or fretting erosion.

\section{CONCLUSIONS}

The electroless nickel coatings may provide a possible solution for the low-cost stationary contact materials, operating under adverse working conditions. The 5-min thermal treatment of the coatings in a high vacuum environment results to a chromium equivalent surface microhardness, which in some cases reaches $2,000 \mathrm{HV}$ locally. The coatings exhibit remarkable electrical performance, and can be well applied on steel substrates. Preliminary work has also shown that other substrates (i.e. brass) may also be employed to increase the bulk electrical and thermal conductivity. The fabrication technique can be applied at an industrial scale and is easy to accomplish. Therefore, it may lead towards new fabrication trends concerning surface preparation of the electrical contact materials.

\section{REFERENCES}

[1] E. Takano and K. Mano, IEEE Trans. Parts, Mater. Packag., PMP, 4 (1968) 51-55.

[2] M. ANTLER, Wear 106 (1985) 5-33.

[3] M. BraunOVIC, Wear 112 (1986) 181-197.

[4] R.B. Waterhouse, Wear 100 (1984) 107-118.

[5] R.D. MaluccI, IEEE Trans. Comp., Hybrids, Manuf. Technol. 15 (1992) 339-347.

[6] J. Swingler and J.W. Mc Bride, IEEE Trans. Comp., Packag., Manuf. Technol. A 21 (1998) 54-60.

[7] E. TAKano and K. Mano, IEEE Trans. Parts, Mater. Packag., PMP, 4 (1968) 51-55.

[8] K. PARKER, Recent Advances in Electroless Nickel Deposits, $8^{\text {th }}$ Interfinish Conference, Basel, 1972.

[9] D. BAudrand and J. Brengston, Met. Finish. J. (1955) 55-57.

[10] G.O. Mallory and J.B. Hajdu, Electroless Plating: Fundamentals and Applications, American Electroplaters and Surface Finishers Society, 1990.

[11] P.S. Kumar and P.K. NAIR, NanoStructured Mater. 4 (1994) 183-198.

[12] T. WatAnABE and Y. TANABE, Trans. Jap. Meatla 24 (1983) 6-40.

[13] A.T. El-Mallah, H.M. Abbas, M.F. Shafei, A.H. ElSAYED and I. NAGI, Plating Surf. Finish. (1989) 124-128.

[14] G.G. Gawrilov, Chemical (Electroless) Nickel plating, Portcullis Pr., LTD, Redhill, 1979, pp. 57-97.

[15] D.W. Baudrand, Electroless Nickel Plating, ASM Handbook, vol. 5, ASM, 1994, pp. 290-305.

[16] K.G. PAUL ANKE, Technical Information about Electroless of Chemical Nickel Plating by the Nibodur Method, Essen, West Germany.

[17] M.H. Staia, E.S. Puchi, G. Castro, F.O. Ramírez and D.B. LEWIS, Thin Solid Films 356 (1999) 472-479.

[18] H.H. UhLIG, Corrosion and corrosion control: An introduction to corrosion science and engineering, John Wiley and Sons, New York, 1971, p. 15.

[19] C.T. Dervos, P. Vassiliou, J. Novakovic and C. Kollia,

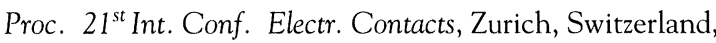
2002, pp. 136-141.

[20] F. Delaunois and P. Lienard, Surf. Coat Technol. 160 (2002) 230-248 